\title{
Makhana (Euryale ferox Salisb.) - cum - fish culture : An integrated management for better yield
}

\author{
B. R. Pramanik ${ }^{1}$ A. M. Puste*2, K. Jana1 ${ }^{1}$ K. Banerjee 2 , D. K. Das ${ }^{2}$ and M. Dasgupta ${ }^{2}$ \\ ${ }^{1}$ Government of West Bengal, West Bengal, \\ ${ }^{2}$ Bidhan Chandra Krishi Viswavidyalaya (Agricultural University),Mohanpur - 741 252, Nadia, West Bengal, \\ India.
}

\begin{abstract}
Integration of makhana (Euryale ferox Salisb.)-cum-fish culture including sole system as sub-plot on the nutritional quality under wetland ecosystem reveal that seed yield as well as nutritional value of makhana seeds (starch, sugar, protein and minerals) vary significantly by different integrated nutrient management (INM) packages applied on the crop and fishes. The result exhibited highest value (75.04, 2.37, 9.45 and $0.52 \%$ ) with $\mathrm{N}_{4}$ treatment (plants and fishes both received a well-balanced organic and inorganic sources of plant nutrients along with fish-feed including zinc spray). The combined effect of different farming system and INM on the nutritional status of makhana seeds was not significant. These important food ingredients as fresh as well as its different value-added products have great importance for small and cottage industries, particularly poor and marginal section of rural people as well.
\end{abstract}

Keywords: Wetland ecosystem; Integration of makhana-cum-fish culture; INM; Yields; Nutritional status of seeds

\section{Introduction}

Among the different crops, makhana or fox nut (Euryale ferox Salisb., Nymphaeaceae) is one of the important underutilized aquatic food crops next to deep-water rice and water chestnut. It is mainly cultivated as a source of starch and protein (Puste 2004). The plant is native to south-east Asia with the prevalence of tropics to sub-tropics accomplished with humid to sub-humid environment. Makhana is an important crop in China, Japan, Malaysia, Thailand, Philippines, Nepal and Bangladesh. It is also grown wild in Russia and North America (Jha and Prasad 1993a). In India, its cultivation is more pronounced in north-eastern part, particularly in northeast of Bihar, where $80 \%$ of India's total production occurs (Misra 1998). It is grown during warmer part of the year, particularly in hot and humid seasons in wetlands having water depth $0.5-3.0 \mathrm{~m}$ or even more.

Besides, it is also considered as nutritive value (Nath and Chakraborty 1985) a powerful tonic for postnatal weakness and acts as an expectorant and cardiac stimulant. Although the related works particularly on scientific culture of makhana as well as more details in analysis of seed quality is practically very less, however, some of works have been done on qualitative aspects of makhana seeds (Nadkarni 1970; Nath and Chakraborty 1985; Anonymous 1989; Jha and Prasad 1993). With number of uses, starch extracted from makhana, is used in textile industries. Because of its economic, social and religious importance, some early studies on its economics were made by Lakhmani (1978).

In fact, scientific investigation, more precisely on the integration of aquatic food crops-cum- fishes, based on mixed farming system, especially with energy-rich live-fishes are meager. For the feasibility of mixed farming rather monoculture along with supply of balanced inputs may bring about the nutritional improvements as a whole. So in the present research a field experiment was conducted during two consecutive pre to post-wet months (January to December) on the effect of various nutrient management and integration of makhana (Euryale ferox Salisb.)-cum-fish culture for quality improvement of makhana seeds in wetland ecosystem of West Bengal.

*Corresponding author. e-mail: <aksayeedsc@gmail.com> 


\section{Materials and methods}

The experiment was carried out in the farmers' field situated at wetland areas of Kalinarayanpur, Nadia, India under new alluvial zone $\left(23^{\circ} \mathrm{N}\right.$ and $89^{\circ} \mathrm{E}$ and $\left.9.75 \mathrm{~m} \mathrm{MSL}\right)$. Two consecutive pre - post-monsoon period (last January to 1st fortnight of December) were considered to see the effect of integrated nutrient management (INM) and makhana (Euryale ferox Salisb.) - cum - fish culture. The soil of the experimental fields (ponds) was heavy clay in texture and mucky in nature, dominated by more clay percentage $(>40 \%)$. The soil resembles the Saluka clay loam which belongs to five hyperthermic mixed family of Andaqueptic Ochraqualf. Initially good quality of makhana seeds were collected from Katihar (Bihar), which have the yield potentiality up to $3.0 \mathrm{t} \mathrm{ha}^{-1}$ and the harvesting duration is about 240 - 250 days (seed to seed) and these were kept in nearby ponds till sprouting of seeds.

The experiment was laid out in a split-plot design with four replications having four levels of INM, viz. $\mathrm{N}_{1}$ - control, $\mathrm{N}_{2}$ - 3 t FYM + 1 t neem oilcake ha ${ }^{-1}$, N3 - 3 t FYM + 1 t neem oilcake + $\mathrm{N}: \mathrm{P}_{2} \mathrm{O}_{5}: \mathrm{K}_{2} \mathrm{O} @ 20: 30: 20 \mathrm{~kg} \mathrm{ha}^{-1}+$ spraying of $\mathrm{Zn}$ (Chelamin) at 20, 40 and 60 DAT of makhana and $\mathrm{N}_{4}$ - 3 t FYM + 1 t neem oilcake $+\mathrm{N}: \mathrm{P}_{2} \mathrm{O}_{5}: \mathrm{K}_{2} \mathrm{O} @ 20: 30$ : $20 \mathrm{~kg} \mathrm{ha}^{-1}+$ spraying of Zn (Chelamin) at 20, 40 and 60 DAT on makhana + fish-feed considered as main plot and having five components of farming systems $(F)$, viz. $F_{1}$ - sole makhana, $\mathrm{F}_{2}$ - sole live-fishes@6,000 fingerlings ha ${ }^{-1}, \mathrm{~F}_{3}$ sole carp fishes@6,000 fingerlings ha ${ }^{-1}, \mathrm{~F}_{4}$ - makhana + live-fishes@4,500 fingerlings ha ${ }^{-1}$ and $\mathrm{F}_{5}$ - makhana + carp fishes@4,500 fingerlings ha ${ }^{-1}$, respectively considered as sub-plot treatment of the experiment, replicated four. Two types of fish variables were stocked in the experimental ponds either as sole or mixed system with makhana, such as live-fish group [Magur (Clarius batrachus), Singhi (Heteropnuestes fossilis) and Sol (Channa striatus)] as well as among the carp fish group, Rohu (Labeo rohita), Mrigal (Cirrhinus mrigala) and Catla (Catla catla) maintaining in a ratio of $4: 3: 3$, respectively.

All individual plots $(8 \mathrm{~m} \mathrm{x} 6 \mathrm{~m})$ were separated through need-based excavation and renovated works during the ear-

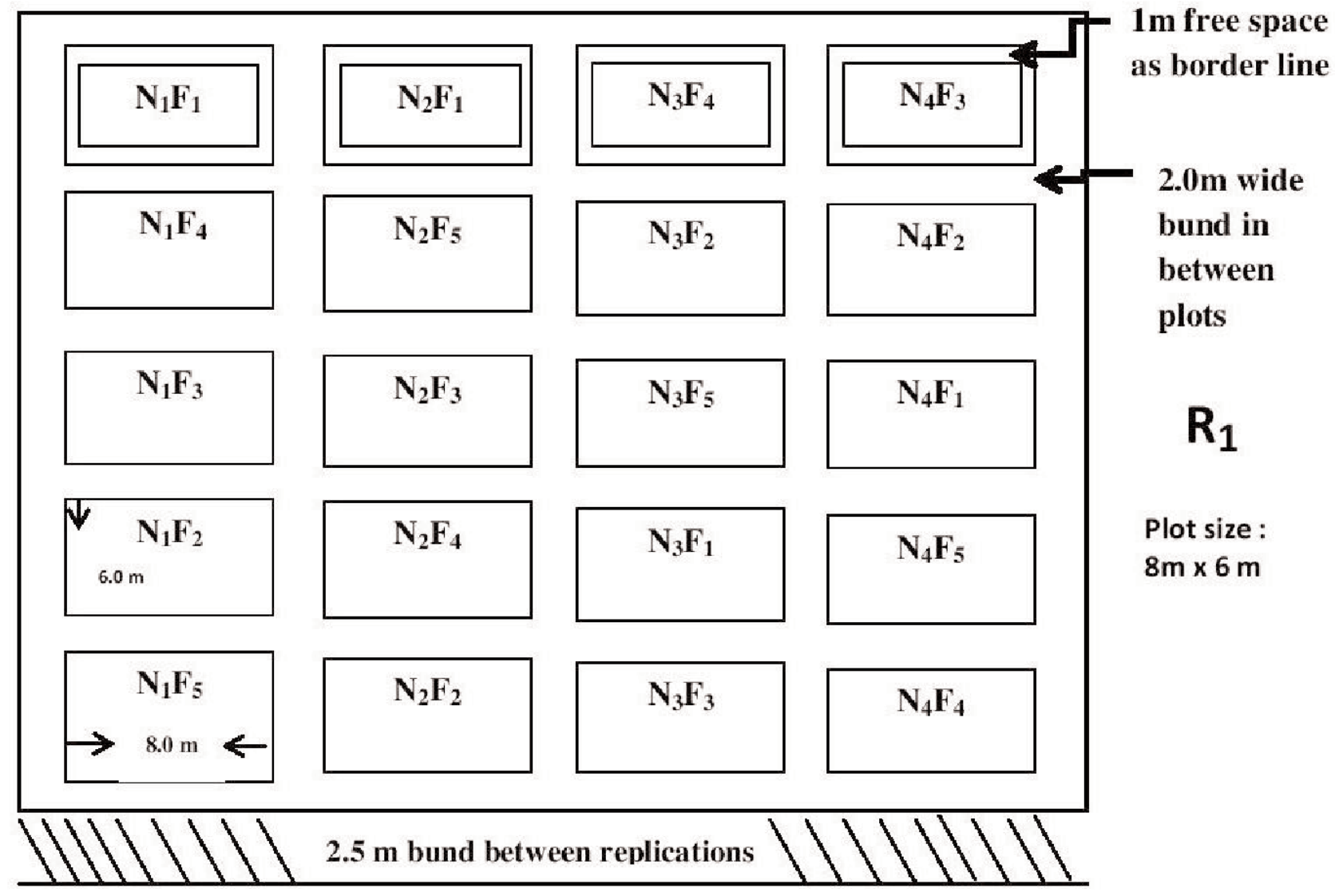

Diagram of the field experiment 
lier part of initial year and sufficient drainage was provided escaping from endangered flush-flood. For this, $2.0 \mathrm{~m}$ high bunds from the bottom of the ponds as well as $0.75 \mathrm{~m}$ top wide were created in all the four sides for maintaining treatment variations. For maintaining identity among the replications, a $2.5 \mathrm{~m}$ wide bunds were also made in between the replications. For the preparation of bunds surrounding the pond, total earth was supplied from the deeper layer of the soil of same pond excluding the upper layer, which was kept aside (i.e. existing mucky soil of $15-20 \mathrm{~cm}$ ). A borderline area of $1.0 \mathrm{~m}$ of individual pond was provided as free water surface for supply of fish-feed as well as easy movement of fishes. The bottom soils of the respective ponds were leveled as far as possible. Addition of lime @ $0.2 \mathrm{ha}^{-1}$ was done initially for purification of pond water as well as soil and for healthy situation of fishes.

Sprouted seeds of makhana were sown uniformly in the nursery pond @ $35 \mathrm{~kg}$ per 0.15 ha during the end of January, which were sufficient for transplanting 1 ha of main ponds area. Before sowing at nursery, seeds were treated with Thirum@2 $\mathrm{g} \mathrm{kg}^{-1}$ and nursery pond was fertilized with well decomposed FYM@1.5 t along with 15 kg fertilizer N ha $^{-1}$. About $60-75 \mathrm{~cm}$ high makhana seedlings having 3-4 leaves were transplanted in the main ponds during March 2025 in each year in a standing water depth of about $50-60 \mathrm{~cm}$ by feet or hand. In sole farming system, seedlings were transplanted @ 1 seedling stool ${ }^{-1}$ maintaining at a spacing of $1.0 \mathrm{~m} \times 1.0 \mathrm{~m}$, while, in mixed farming systems (makhana + fishes) it was maintained at a spacing of $1.5 \mathrm{~m} \mathrm{x} 1.0 \mathrm{~m}$ row to row and plant to plant, respectively. Before transplanting, all the seedlings were treated with Chlorpyriphos $0.2 \%+$ Captan $0.1 \%$ solution by root-dipping for 6-8 hours. FYM, neem oilcake and chemical fertilizers were applied as per the treatment specified in the experiment. As the depth of water body was high, foliar applications of $\mathrm{Zn}$ in the form of Chelamin@0.2\% with water@3001 ha ${ }^{-1}$ were done during the growth stages of the crop.

Both types of fingerlings were 5-8 cm length having 5-6 $\mathrm{g}$ and 8-10 $\mathrm{cm}$ length having 8-10 $\mathrm{g}$ average individual body weight of carp and live-fishes were stocked in the respective ponds during the middle of July after initial establishment of makhana for synchronous effect of fishes on the crop. Fishfeed of powdered mustard oilcake and rice bran were mixed with the ratio of 1:1 and applied @ 10\% of average body weight of fishes at 7 days interval. A regular catching of fishes was done at an interval of 30 days for checking the growth. After harvesting of makhana seeds, fishes were allowed to grow further till catching during the end of December.

During both the years makhana seeds collected randomly from each plot for determining starch, sugar, protein and minerals following Sadasivam and Manickam (1996). Then the seeds were grounded and separated the seed coat and kept for nutritional analysis in the laboratory.

Makhana seeds were harvested with the help of sieve like container called Polo. In the experiment, this job was performed manually during the last part of November or first fortnight of December. After collection, seeds from the respective ponds were thoroughly threshed manually to obtain black colour glossy seeds. The seeds were then thoroughly washed with clean water and considered as harvesting produce and weighted after draining excess water from it. Viable seeds were again dipped in water till seedling emerges during last part of January for next. However, the processed seeds were used for popped food.

\section{Results and discussion}

It revealed from the experimental data that makhana seeds as well as both the fish groups (live and carp) were markedly influenced by the varying integrated nutrient management practiced on the crop (Table I). Maximum seed and both fish yield of 2.192, 0.501 and $1.009 \mathrm{t} \mathrm{ha}^{-1}$ was obtained with the application of $\mathrm{N}_{4}$ treatment and resulted 64.93, 89.06 and $53.11 \%$ more yield increment in makhana, live and carp fishes over the control plots $\left(\mathrm{N}_{1}\right)$, respectively. The yield increment in this treatment $\left(\mathrm{N}_{4}\right)$ might be due to the beneficial effect of combined integrated nutrient management, which was applied through well balanced organic manures as well as inorganic sources of plant nutrients including recurring supply of organic fish-feed materials. From the results it also revealed that this treatment also exhibited significant highest total makhana equivalent yield (MEY) of $2.543 \mathrm{t} \mathrm{ha}^{-1}$, respectively in pool analyzed data (Table I), which is $63.54 \%$ more than that of control. This might be due to the balanced INM, which was helpful for the growth of phytoplankton 
Table I. Effect of INM and integration of makhana-fish farming systems on the yield and total yield advantage of the system (pooled analyzed of 2 years)

\begin{tabular}{lcccc}
\hline \multirow{2}{*}{ Treatment } & \multicolumn{3}{c}{ Yield $\left(\mathrm{t} \mathrm{ha} \mathrm{C}^{-1}\right)$} & Total MEY $\left(\mathrm{t} \mathrm{ha}^{-1}\right)$ \\
\cline { 2 - 3 } & Makhana & Live-fishes & Carp fishes & \\
\cline { 2 - 3 } INM (N) & & & & 1.555 \\
$\mathrm{~N}_{1}$ & 1.329 & 0.265 & 0.659 & 1.877 \\
$\mathrm{~N}_{2}$ & 1.761 & 0.366 & 0.787 & 2.341 \\
$\mathrm{~N}_{3}$ & 2.069 & 0.434 & 0.951 & 2.543 \\
$\mathrm{~N}_{4}$ & 2.192 & 0.501 & 1.009 & 0.0079 \\
S.Em. $( \pm)$ & 0.043 & 0.0239 & 0.0131 & 0.0252 \\
C.D. $(P=0.05)$ & 0.134 & 0.074 & 0.0387 & \\
Farming Systems $(\mathrm{F})$ & & & & 2.145 \\
$\mathrm{~F}_{1}$ & 2.274 & -- & -- & 1.653 \\
$\mathrm{~F}_{2}$ & -- & 0.467 & -- & 1.364 \\
$\mathrm{~F}_{3}$ & -- & -- & 1.067 & 2.831 \\
$\mathrm{~F}_{4}$ & 1.659 & 0.334 & -- & 2.391 \\
$\mathrm{~F}_{5}$ & 1.581 & -- & 0.633 & 0.029 \\
S.Em. $( \pm)$ & 0.055 & 0.0092 & 0.0211 & 0.088 \\
C.D. $(P=0.05)$ & 0.168 & 0.0291 & 0.0652 & \\
\hline
\end{tabular}

and zooplankton and ultimately better growth of fishes as well as the positive effect of regulated fish-feed materials.

It visualized from the experiment that different types of integrated farming system were significantly differed in respect to their individual yield (seed yield of makhana and both fish yield), shared yield in combined system and total equivalent yield in individual and combined system (Table I). Due to different farming systems of makhana + two types of fish groups, effect of different farming systems on the seed yield of makhana, highest yield was obtained with sole crop, sole fish etc. $\left(F_{1}\right)$ and this was due to the lower spacing vis-à-vis more plant population than any other mixed stand of makhana + fish variables because of their less shared area including population. Minimum seed yield of makhana (1.581 $\mathrm{t} \mathrm{ha}^{-1}$ ) was comparatively lower in mixed stand of makhana + live-fishes $\left(\mathrm{F}_{5}\right)$, even than that of makhana + carp fishes (1.659 $\mathrm{t} \mathrm{ha}^{-1}$ in $\mathrm{F}_{4}$ treatment), probably due to more compatibility of makhana with this fish groups. Between two farming systems, $\mathrm{F}_{4}$ treatment (makhana + live-fishes farming system) gave the highest value of total makhana equivalent yield (2.831 t ha $\mathrm{ha}^{-1}$ ), which was closely followed by $\mathrm{F}_{5}$ (makhana + carp fishes) obtained $2.391 \mathrm{t} \mathrm{ha}^{-1}$ in this farming system. Among the total farming systems significant lowest total MEY of $1.364 \mathrm{t} \mathrm{ha}^{-1}$ was obtained with sole carp fishes $\left(\mathrm{F}_{3}\right)$. It is observed that an additional yield increment in $\mathrm{F}_{4}$ treatment over either sole or mixed farming systems was to the tune of 31.98 to $107.55 \%$ due to integration as well as more sharing remunerative value of live-fishes in the market.

During first and second year of experiment as well as in pooled analyzed data, the results observed that due to the application of different INM packages, ingredients like starch and protein content of makhana seeds was influenced significantly and highest value of starch and protein (75.04 and $9.45 \%$ ) and were found in $\mathrm{N}_{4}$ (Table II). Although sugar and minerals did not differ significantly, however, highest results $(2.37$ and $0.52 \%)$ were obtained with this treatment also. In most of the cases there were no significant differences with $\mathrm{N}_{3}$ and $\mathrm{N}_{2}$ treatments. Lowest results of all the ingredients $(70.16,2.09,8.08$ and $0.41 \%$, respectively) were obtained with chemical fertilizers alone. The combined effect of different farming system and INM on the nutritional status of makhana seeds was not significant. 
Table II. Effect of INM and makhana-cum-fish farming systems on the nutritional status of makhana seeds

\begin{tabular}{|c|c|c|c|c|c|c|c|c|c|c|c|c|}
\hline \multirow[t]{3}{*}{ Treatments } & \multicolumn{12}{|c|}{ Nutritional status of makhana seeds (\%) } \\
\hline & \multicolumn{3}{|c|}{ Starch } & \multicolumn{3}{|c|}{ Sugar } & \multicolumn{3}{|c|}{ Protein } & \multicolumn{3}{|c|}{ Minerals } \\
\hline & 2007 & 2008 & Pooled & 2007 & 2008 & Pooled & 2007 & 2008 & Pooled & 2007 & 2008 & Pooled \\
\hline \multicolumn{13}{|c|}{ Integrated nutrient management $(\mathrm{N})$} \\
\hline $\mathrm{N}_{1}$ & 70.52 & 69.82 & 70.16 & 2.06 & 2.11 & 2.09 & 8.13 & 8.02 & 8.08 & 0.41 & 0.40 & 0.41 \\
\hline $\mathrm{N}_{2}$ & 72.78 & 73.14 & 72.97 & 2.13 & 2.16 & 2.15 & 8.67 & 8.82 & 8.75 & 0.46 & 0.47 & 0.47 \\
\hline $\mathrm{N}_{3}$ & 74.25 & 74.76 & 74.48 & 2.17 & 2.23 & 2.20 & 9.18 & 9.34 & 9.26 & 0.47 & 0.49 & 0.48 \\
\hline $\mathrm{N}_{4}$ & 74.68 & 75.38 & 75.04 & 2.38 & 2.36 & 2.37 & 9.36 & 9.53 & 9.45 & 0.51 & 0.52 & 0.52 \\
\hline S.Em. $( \pm)$ & 0.896 & 0.938 & 0.917 & 0.109 & 0.087 & 0.096 & 0.240 & 0.253 & 0.247 & 0.037 & 0.043 & 0.039 \\
\hline C.D. $(P=0.05)$ & 2.76 & 2.89 & 2.83 & N.S. & N.S. & N.S. & 0.74 & 0.78 & 0.76 & N.S. & N.S. & N.S. \\
\hline \multicolumn{13}{|c|}{ Farming Systems (F) } \\
\hline $\mathrm{F}_{1}$ & 74.32 & 75.12 & 74.71 & 2.31 & 2.31 & 2.28 & 9.17 & 9.39 & 9.28 & 0.48 & 0.51 & 0.50 \\
\hline $\mathrm{F}_{4}$ & 73.61 & 74.26 & 73.93 & 2.11 & 2.16 & 2.14 & 9.03 & 9.18 & 9.11 & 0.46 & 0.48 & 0.47 \\
\hline $\mathrm{F}_{5}$ & 73.45 & 73.98 & 73.69 & 2.18 & 2.23 & 2.21 & 8.94 & 9.02 & 8.98 & 0.43 & 0.45 & 0.44 \\
\hline S.Em. $( \pm)$ & 0.306 & 0.388 & 0.348 & 0.069 & 0.053 & 0.048 & 0.081 & 0.131 & 0.103 & 0.019 & 0.023 & 0.026 \\
\hline C.D. $(P=0.05)$ & N.S. & N.S. & N.S. & N.S. & N.S. & N.S. & N.S. & N.S. & N.S. & N.S. & N.S. & N.S. \\
\hline
\end{tabular}

Cropping systems (sole as well as mixed farming of makhana + fish variables) did not vary significantly neither any of the years or in pooled analyzed data (Table II). In this regard, integration of the system was not able to score highest on the qualitative aspects of makhana seeds (starch, sugar, protein and minerals), however, in sole system of makhana seeds was able to produce higher value of all these food ingredients $(74.71,2.28,9.28$ and $0.50 \%$, respectively), might be due to not disturbance of water media as sole crop than that of mixed farming system. Comparatively lower value of all the nutritional quality viz. starch, sugar, protein and minerals $(73.69,2.14,8.98$ and $0.44 \%$, respectively) obtained in seeds of makhana, grown as mixed with either live or carp fishes under mixed farming system, may be due to more competition in respect to food, light and space in wet situation of mixed farming.

Among the aquatic food crops, makhana (Euryale ferox Salisb.) is an important underutilized crop, grown divergence of wetland ecosystem mostly in neglected way, resulted poor yields. Improvised agro-techniques including integration with fishes may change the production scenario of both crop and fishes including its nutritional status that ben efited for the farming community and cottage industries for its value-added products as well.

\section{Acknowledgment}

The Indian Council of Agricultural Research and the Department of Land Resources, Ministry of Rural Development, Government of India for financial support and the Department of Agronomy and Soil Science, Bidhan Chandra Krishi Viswavidyalaya and the local farmers for providing the necessary facilities during the field trials are gratefully acknowledged.

\section{References}

Anonymous (1989), The Wealth of India - Raw Materials, published by Publications and Information Directorate, CSIR, New Delhi, III. (D-E) : 232.

Jha SN and Prasad S (1993a), J. Food Sci. Technol., 30: 163-165.

Jha SN and Prasad S (1993), Proceedings of annuals convention of I. S. A. E. Bhopal, March : 5-7.

Lakhmani AK (1978), M. Sc. (Ag.) Thesis, Rajendra Agricultural University, Bihar, India. 
Misra RL (1998), Gorgon plant: an aquatic ornamental, Indian Hort. (Jan-Feb): 20-21.

Nadkarni AK (1970), Indian Materia Medica, Popular Prakasan, Bombay. I: 530.

Nath BK and Chakraborty AK (1985), Studies on amino acid composition of the seeds of Euryale ferox Salisb. J. Food Science Technol. 22: 293.
Puste AM (2004), In: Agronomic Management of Wetland Crops. Published by Kalyani Publishers, Ludhiana, India.

Sadasivam S and Manickam A (1996), In: Biochemical Methods. P. 6, 11 and 56.

Received: 04 October 2012; Revised: 01 August 2013; Accepted: 17 December 2013. 